\title{
Effectiveness of Structural and Nonstructural Measures on the Magnitude and Uncertainty of Future Flood Risks
}

\author{
N. Fajar Januriyadi1* ${ }^{*}$, So Kazama², Idham R. Moe ${ }^{3}$, Shuichi Kure ${ }^{4}$ \\ ${ }^{1}$ Department of Civil Engineering, Pertamina University, Jakarta, Indonesia \\ ${ }^{2}$ Department of Civil Engineering, Tohoku University, Sendai, Japan \\ ${ }^{3}$ Ministry of Public Works and Housing, Jakarta, Indonesia \\ ${ }^{4}$ Department of Environment and Civil Engineering, Toyama Prefectural University, Imizu, Japan \\ Email: *nurul.fj@universitaspertamina.ac.id
}

How to cite this paper: Fajar Januriyadi, N., Kazama, S., Moe, I.R. and Kure, S. (2020) Effectiveness of Structural and Nonstructural Measures on the Magnitude and Uncertainty of Future Flood Risks. Journal of Water Resource and Protection, 12, 401-415.

https://doi.org/10.4236/jwarp.2020.125024

Received: March 26, 2020

Accepted: April 25, 2020

Published: April 28, 2020

Copyright $\odot 2020$ by author(s) and Scientific Research Publishing Inc. This work is licensed under the Creative Commons Attribution International License (CC BY 4.0).

http://creativecommons.org/licenses/by/4.0/

\begin{abstract}
The purpose of this research is to assess the effectiveness of various adaptation measures in reducing the magnitude and uncertainty of future flood risks in Jakarta, a megacity in Indonesia. A flood inundation model and a flood damage costs model were developed to evaluate their effectiveness. Land use changes, land subsidence, and climate change were used to describe the future scenarios. The adaptation measures include both structural and nonstructural measures. The results show that recharge and retention ponds have the potential to reduce the magnitude and uncertainty of flood risks by $33.2 \%$ and $36.4 \%$, respectively, which are higher than the potentials of the other structural adaptation measures. Among the nonstructural adaptation measures, managing land use zones could alleviate the magnitude of flood risks by $29.0 \%$, with an uncertainty reduction of $19.9 \%$. These findings will assist decision makers in selecting flood adaptation measures to address future environmental changes.
\end{abstract}

\section{Keywords}

Jakarta, Adaption Measures, Uncertainty, Land Use Change, Land Subsidence, Climate Change

\section{Introduction}

Floods are among the major natural disasters that impact millions of people every year worldwide. Changes in the environment (e.g., climate change and land cover change) potentially intensify future flood risk. Some studies have 
shown that the future flood risk is expected to increase due to climate change and land cover. Hirabayashi et al. [1] showed a large increase in flood frequency in some regions due to climate change, namely, Southeast Asia, Peninsular India, eastern Africa and the northern half of the Andes. Bradshaw et al. [2] showed evidence that the decrease in natural forest in some developing countries could increase flood frequency and duration. The change in the environment not only changes the flood risk but also increases the uncertainty of future floods. Januriyadi et al. [3] showed that climate change is expected to increase the future flood risk by $54 \%$ - $100 \%$, while the combination of climate change and urban development potentially increases the future flood risk by $322 \%-402 \%$. The different percentages of the increase in flood risk show the uncertainty of future flood risks. The study showed that more combinations of environmental change are expected to increase the uncertainty of future flood risks.

To address flood hazards, various adaptation measures (i.e., either structural or nonstructural measures) have been utilized. Moe et al. [4] examined the reduction in the inundation frequency and volume by improving the river capacity in Jakarta. They found that a $150 \%$ increase in the river capacity could reduce flood inundation by $15 \%$. The construction of embankments or levees represents one option for increasing river capacity [5] [6], and these options are sometimes combined with nature-based protection [7] [8] [9]. In addition, nonstructural measures, such as early warning systems, could alleviate the damage costs caused by floods [10] [11]. However, the evaluation of the adaptation measures to reduce flood risks should consider not only the magnitude but also the uncertainty.

Based on the above explanation, future floods are expected to increase not only in magnitude but also in uncertainty. To reduce the magnitude and uncertainty of future floods, this study applies several adaptation measures, either structural or nonstructural. We used flood damage costs to evaluate the magnitude of flood risk and the confidence interval to evaluate flood uncertainty. Jakarta City was selected as the study site because its characteristics can be classified as a megacity of a developing country, as explained in the next section. The research is expected to provide insight into selection in flood adaptation measures to reduce future flood risk.

\section{Study Area}

Jakarta, the capital city of Indonesia, is located in the western part of Java Island, as shown in Figure 1. Jakarta is the densest city in Indonesia, with a population density of approximately 15,000 people per $\mathrm{km}^{2}$. Several rivers pass through Jakarta, and the main river is the Ciliwung River. Excluding Jakarta, the basins of the rivers cover five cities and three regencies, which are categorized as developing regions with a varied population growth rate of $2.04 \%$ to $5.14 \%$.

Flooding is one of the severe problems in Jakarta. Hundreds of people have died due to flood events and millions of people have been affected. Weather and 


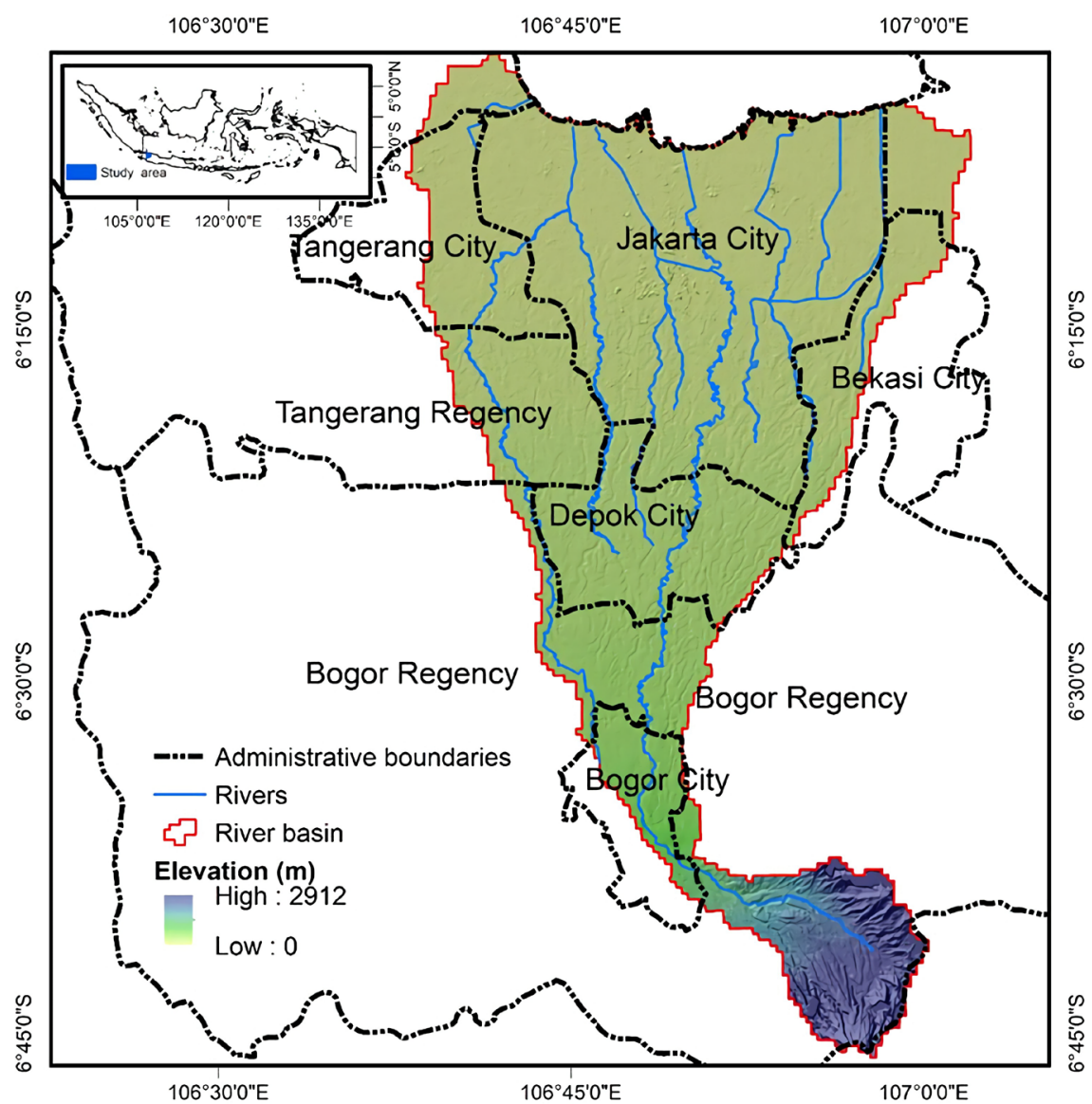

Figure 1. Geographic and topographic map of the study area (the red line is the border line of the Jakarta Rivers Basin).

topographical conditions are the factors that contribute to flooding in Jakarta. Rapid urbanization also amplified the flood problems in Jakarta. Farid et al. [12] found that the peak discharge under 2002 land cover conditions was 1.2 times the peak discharge under 1996 land cover. Jakarta also has a land subsidence problem that potentially increases the flood risk in Jakarta. Abidin et al. [13] observed the land subsidence phenomenon in Jakarta from 1982 to 2010. The observed subsidence rates were approximately $1-15 \mathrm{~cm} /$ year and can be up to 20 $28 \mathrm{~cm} /$ year at particular locations and during particular periods.

\section{Methodology}

\subsection{Flood Inundation Model}

A flood inundation model of Jakarta was developed by previous studies [14]. The model was conducted in three modules: the rainfall runoff module, the river flow module, and the inland flow module. They calibrated the flood inundation model using radar rainfall data. They found that the correlation coefficient between observations and simulated averages is 0.8 . Januriyadi et al. [3] also employed the model for evaluating future flood risk under land use change, land subsidence, and climate change scenarios. They assessed the climate change im- 
pacts using the precipitation of eight global climate models (GCMs) [15]-[22] with three emission scenarios (RCP 2.6, RCP 4.5 and RCP 8.5), which were corrected for biases to the observed precipitation using a quantile mapping bias correction method.

\subsection{Damage Cost Estimation}

The study used flood damage costs to represent the flood risk. Damage cost estimation was divided into two steps. First, the damage costs were estimated based on return period rainfall events. Second, the expected annual damage costs (EADC) were calculated. The damage cost estimation was based on the land use classification. We used the damage-depth function of the Ministry of Land, Infrastructure, Transportation, and Tourism [23] applied by Kazama et al. [24] to estimate the flood damage costs throughout all of Japan.

Furthermore, the EADC were calculated by integrating the flood damage costs over the overall return periods [25]. This model assumes that the flood damage costs correspond to the depth of inundation. Kreibich and Dimitrova [26] found that the water level of floods has a significant connection to flood damage costs, especially for riverine floods.

\subsection{Adaptation Measure Scenarios}

This study used two categories of adaptation measures (i.e., structural and nonstructural). Each category has several options for adaptation measures. Recharge and retention ponds (RRPs), recharge wells (RWs), seawall protection (SWP) and green infrastructure (GI) are included in the structural category, while the nonstructural category consists of land subsidence control (LSC) and land use zoning (LUZ).

\subsubsection{Recharge and Retention Ponds}

The concept of RRPs is a structural adaptation measure that uses some large ponds inside the city to reduce flood risk. The ponds have the capacity to recharge water into the soil and retain floodwater. The ponds are also along rivers with side spillways. When the water depth in the river reaches a specific level, the water will spill out into the ponds. The water discharge on the spillway is calculated using Honma's equation [27]. Moreover, the infiltration rate in the pond is estimated using Darcy's equation on the inundated soil [28]. This study used three large ponds with a total area of $14.5 \mathrm{~km}^{2}$. The ponds are in three locations. Two of them are in the northwest and northeast parts of Jakarta, where the confluence of rivers is located. The third pond is in the Ciliwung River, which is the main river in Jakarta. The locations of the ponds are based on the damage costs due to flooding. [29] spatially identified three locations with high flood damage costs in Jakarta city (i.e., the northwest, northeast, and central parts of Jakarta). Moreover, the northeast and northwest parts have high land subsidence rates [13]. These situations are considered to determine the locations of RRPs; therefore, they can not only reduce flood risk but also mitigate the land subsi- 
dence problem in Jakarta city.

\subsubsection{Recharge Wells}

An RW is a well that not only stores floodwater but also recharges the water into the ground. This study assumes that the soil type in the whole basin is uniform. Therefore, the recharge rates of an RW can be calculated using Zangar's equation for reverse auger-hole flow [28]. In the simulation, the RWs are involved in the rainfall runoff module, with an assumption that the average density of RWs is $200 \mathrm{RWs}$ per $\mathrm{km}^{2}$. Therefore, the RWs reduced the discharge input in the river flow module.

\subsubsection{Seawall Protection}

The idea of the SWP effect comes from the current government's project named the Garuda project, which constitutes a giant seawall that will protect northern Jakarta from tidal surges [30]. The project is expected to protect Jakarta city from coastal flooding and to quickly drain floodwater from the rivers by pumping. By assuming that this project will be successful and that it could reduce the seawater level by $1.0 \mathrm{~m}$, we simulated the effects of lowering the seawater level and calculated the reduction in flood risk. The SWP effect involves flood simulation by reducing the boundary condition downstream in both the river flow module and the inland flow module.

\subsubsection{Green Infrastructure}

The "renaturing of cities" through GI could produce multiple benefits [31], such as a cooling effect [32] and the absorption of $\mathrm{CO}_{2}$ [33]. This study assumed that the types of GI are greenery walls and roofs, which have an average storage capacity of 2 litter $/ \mathrm{m}^{2}$. We also assumed that GI covers all the urban areas.

\subsubsection{Land Subsidence Control}

Land subsidence is one of the factors that contributes to the increase in flood risk in Jakarta [3] [34]. The land subsidence rates in Jakarta are proportional to the amount of groundwater extraction [13]. Reducing groundwater withdrawal could prevent the land subsidence problem. On the other hand, the government of Indonesia has a plan to supply $100 \%$ of the water demand to the people by 2019 [35]. Land subsidence linearly lowers the ground elevation. This study estimated the flood risk reduction by assuming that this government policy can stop land subsidence under three scenarios (i.e., stop by 2020, 2030, and 2040).

\subsubsection{Land Use Zoning}

Moving away from a disaster area is one option to reduce damage costs [36]. Laws and regulations, including land zoning, could minimize economic losses due to disasters. People who stay near rivers and oceans are susceptible to floods. This study calculated the reduction in flood damage costs by assuming that people will tend to avoid living within $500 \mathrm{~m}$ of the beach line and $25 \mathrm{~m}$ away from the riverside. 


\subsection{Baseline Condition}

Januriyadi et al. [3] studied the change in flood risk in Jakarta due to future scenarios. They used three future scenarios, namely, land use change, land subsidence, and climate change. The land use change scenario was based on the land use projection in 2050. The projected land use was developed by Varquez et al. [37]. Furthermore, the land subsidence scenarios were based on the linear projection in 2050 using the current land subsidence rate. The land subsidence rates in Jakarta were measured by Abidin et al. [13]. Moreover, the climate change scenario used daily precipitation data of eight GCM outputs with three RCP scenarios. They divided the period into two categories, near-future (2011-2050) and far-future (2051-2100). They found that both near- and far-future flood risk is expected to increase significantly compared to that under current conditions.

This study used the projected flood risk of Januriyadi et al. [3]. The baseline scenario for the near future has a mean EADC of $3271 \pm 286$ million USD with a confidence interval of 95\%, whereas for the far future, it has a mean EADC of $3535 \pm 325$ million USD. Figure 2 shows the box and whisker chart of EADC for the near- and far-future. The figure indicates the high uncertainty of future flood risk. The figure is used as the baseline values for the future flood risk in this study. This study evaluates how the adaptation measures reduce the baseline flood risk, as explained in the next subsection.

\section{Results}

\subsection{Flood Risk Reduction}

Generally, this section describes the reduction in the EADC after applying adaptation measures. Figure 3 shows a comparison for each adaptation measure scenario. A decrease in the EADC represents flood risk reduction. Table 1 presents a summary of the effectiveness of the different structural and nonstructural measures.

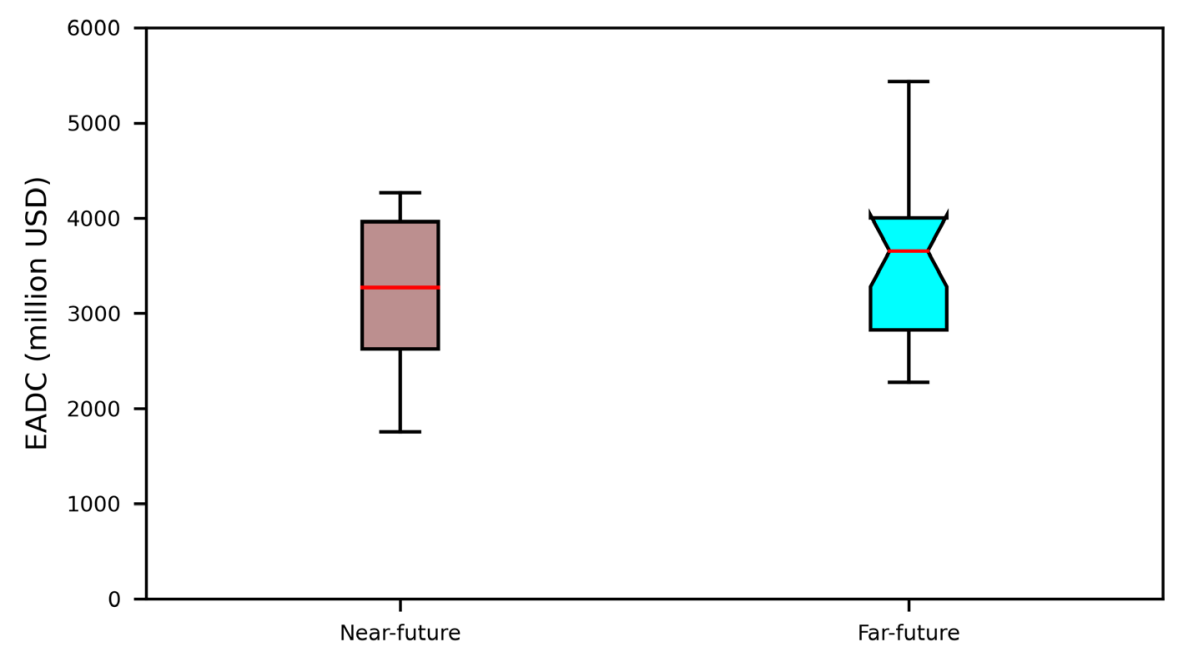

Figure 2. Expected annual damage costs (EADC) for future scenarios (near- and far-future) as the baseline values before applying adaptation measures (horizontal red line indicates the median value of EADC). 


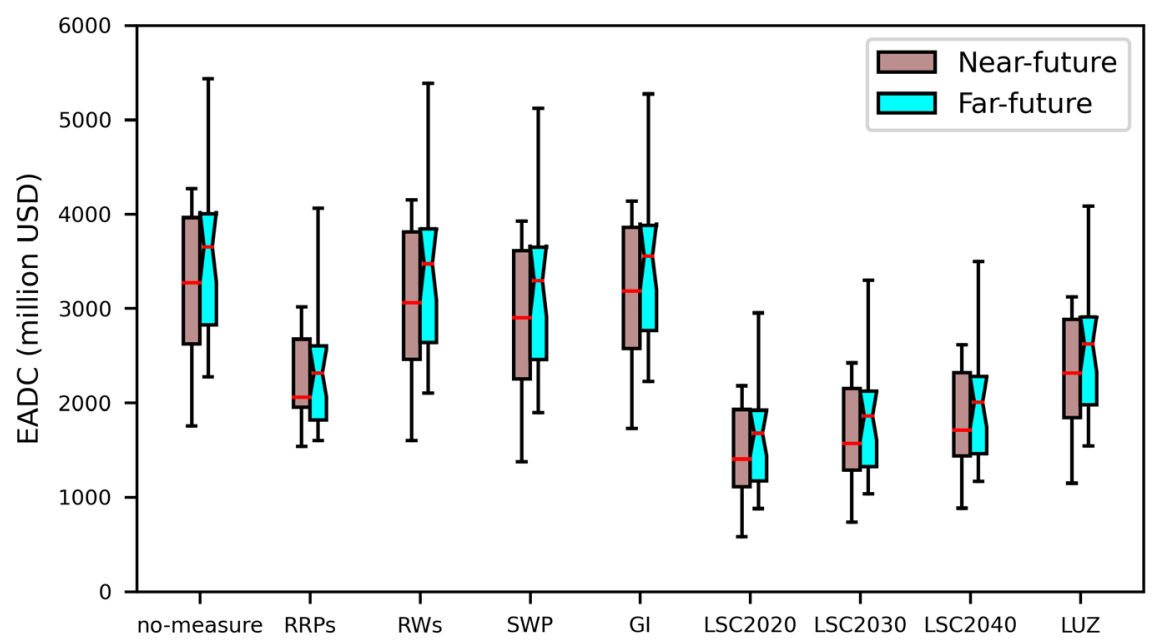

Figure 3. Comparison of expected annual damage costs (EADC) for each scenario (horizontal red line indicates the median value of EADC).

Table 1. Summary of the effectiveness of the different structural and nonstructural measures.

\begin{tabular}{ccccccc}
\hline \multirow{2}{*}{$\begin{array}{c}\text { Adaptation } \\
\text { measures }\end{array}$} & \multicolumn{2}{c}{$\begin{array}{c}\text { Mean of EADC } \\
\text { (million USD) }\end{array}$} & \multicolumn{4}{c}{ Flood risk reduction (\%) } \\
\cline { 2 - 7 } & Near-future & Far-future & Near-future & Far-future & Near-future & Far-future \\
\hline RPPs & $2186 \pm 182$ & $2186 \pm 253$ & 33.2 & 32.8 & 36.4 & 22.1 \\
RWs & $3089 \pm 296$ & $3366 \pm 340$ & 5.6 & 4.8 & -3.6 & -4.7 \\
SWP & $2907 \pm 291$ & $3176 \pm 332$ & 11.1 & 10.1 & -1.7 & -2.1 \\
GI & $3186 \pm 274$ & $3441 \pm 313$ & 2.6 & 2.7 & 4.2 & 3.6 \\
LSC2020 & $1459 \pm 184$ & $1639 \pm 220$ & 55.4 & 53.6 & 35.7 & 32.3 \\
LSC2030 & $1640 \pm 197$ & $1836 \pm 239$ & 49.9 & 48.1 & 31.1 & 26.5 \\
LSC2040 & $1789 \pm 201$ & $1990 \pm 246$ & 45.3 & 43.7 & 29.7 & 24.3 \\
LUZ & $2322 \pm 229$ & $2535 \pm 264$ & 29.0 & 28.3 & 19.9 & 18.8 \\
\hline
\end{tabular}

\subsubsection{Recharge and Retention Ponds}

RRPs were located in an area with high inundation depths and high land subsidence rates. There were three large ponds in this study. The calculation of the EADC also considered the inundation of these ponds. The results show that after RRPs are installed into the model, the mean EADC for the near future becomes $2186 \pm 182$ million USD, while for the far future, it becomes $2186 \pm 253$ million USD. The reduction in the magnitude of the flood risk for the near future is $33.2 \%$, while for the far future, it is $32.8 \%$. RRPs could reduce the flood inundation by diverging the flood water into ponds to avoid it inundating areas with high asset values. RRPs could alleviate the uncertainty of near-future and far-future flood risk by $36.4 \%$ and $22.1 \%$, respectively.

\subsubsection{Recharge Wells}

The RWs distributed throughout the whole basin slightly reduced the flood 
damage costs. The results show that the mean EADC after RWs installation for the near- and far-future periods are $3089 \pm 296$ and $3366 \pm 340$ million USD, respectively, reductions of $5.6 \%$ and $4.8 \%$, respectively. RWs could slightly reduce the flood inundation by storing some amount of floodwater and infiltrating it into the soil. In contrast to RRPs, RWs fail to reduce the uncertainty of flood risk, which is shown by the negative values of uncertainty reduction percentages of $-3.6 \%$ and $-4.7 \%$.

\subsubsection{Seawall Protection}

As mentioned in the previous section, the Indonesian government is constructing a giant seawall to protect the northern beach of Jakarta. Based on our simulation, the results show that the mean EADC for the near- and far-future periods become $2907 \pm 291$ and $3176 \pm 332$ million USD, respectively, if the project can reduce the seawater level by $1.0 \mathrm{~m}$. The lower seawater level could alleviate the flood inundation in the land. This outcome means that the magnitude of the reductions is $11.1 \%$ and $10.1 \%$, respectively. Similar to RWs, SWP fails to reduce the uncertainty of floods by $-1.7 \%$ and $-2.1 \%$, respectively.

\subsubsection{Green Infrastructure}

Furthermore, GI only slightly reduces the EADC compared with those of the other structural adaptation measures. The results show that GI reduces the mean EADC for the near- and far-future periods to $3186 \pm 274$ and $3441 \pm 313$ million USD, respectively. The flood magnitude reductions for the near- and far-future are $2.6 \%$ and $2.7 \%$, respectively. Some amount of rainfall water stored in the vegetation leaves could reduce the rainfall that directly contributes to the rainfall-runoff process. The uncertainty reductions for the near- and far-future are $4.2 \%$ to $3.6 \%$.

\subsubsection{Land Subsidence Control}

Controlling land subsidence could avoid high economic losses due to flooding. Flood risk reduction depends on the success of stopping land subsidence. If land subsidence stops by 2020, the mean EADC could be reduced to $1459 \pm 184$ and $1639 \pm 220$ million USD for the near and far future, respectively. If land subsidence continues until 2030, the mean EADC for the near- and far-future will become $1640 \pm 197$ and $1836 \pm 239$ million USD, respectively. The scenario with land subsidence continuing until 2040 could alleviate the mean EADC to $1789 \pm$ 201 and $1990 \pm 246$ million USD for the near- and far-future, respectively.

\subsubsection{Land Use Zoning}

Regulations on land use zoning are also effective for reducing damage costs. The results show that migrating land use away from beaches and rivers could decrease the EADC for the near- and far-future periods to $2322 \pm 229$ and $2535 \pm$ 264 million USD, respectively. The reductions in flood magnitude for the nearand far-future periods are $29.0 \%$ and $28.3 \%$, respectively; the reductions in uncertainty are $19.9 \%$ and $18.8 \%$, respectively. 


\subsection{Benefit Cost Analysis}

In terms of evaluating the effectiveness of the adaptation measures, the authors also evaluated the benefit cost ratio. The benefits are obtained from the differences between the EADC before and after installing the adaptations in the flood model. There are different ways of estimating the cost for each adaptation measure. The costs for RRPs and LUZ were estimated by assuming that the costs are similar to the building prices of the area used for ponds and relocations, which are 2521 and 3334 million USD, respectively. Based on the JICA report [38], the average cost required to construct a single well with a storage capacity of $1 \mathrm{~m}^{3}$ is approximately IDR 70,000. This study applied a recharge well volume of 62.8 $\mathrm{m}^{3} / \mathrm{ha}$. Therefore, the total subsidy for infiltration wells in the whole river basin is approximately 700 billion IDR or 72 million USD (2005 exchange rate). Moreover, the cost of the Garuda project is 40 billion USD [39]. For green infrastructure, Toho-Leo's expert mentioned that the cost of constructing one $\mathrm{m}^{2}$ of green roof or wall is approximately 75 USD. Moreover, the maintenance costs were assumed to be $10 \%$ of the construction costs. The interest and duration were assumed to be $10 \%$ and 50 years, respectively.

The result of the benefit-cost ratio (BCR) is presented in Figure 4. The figure shows that GI and SWP produce minimal BCR values, with mean BCR values of $0.004 \pm 0.001$ and $0.045 \pm 0.001$, respectively, while RRPs have a BCR mean value of $2.193 \pm 0.226$. The BCR value of RRPs could decrease if the calculation includes the construction costs. Furthermore, recharge wells have the highest BCR value (i.e., $9.076 \pm 0.777$ ). Even though the benefit value of RWs is smaller than that of RRPs and SWP, the construction costs of RWs are much cheaper than those of the other adaptation measures.

\section{Discussion}

Different types of adaptation measures have been applied to reduce the magnitude and uncertainty of future flood risks. These adaptation measures give different

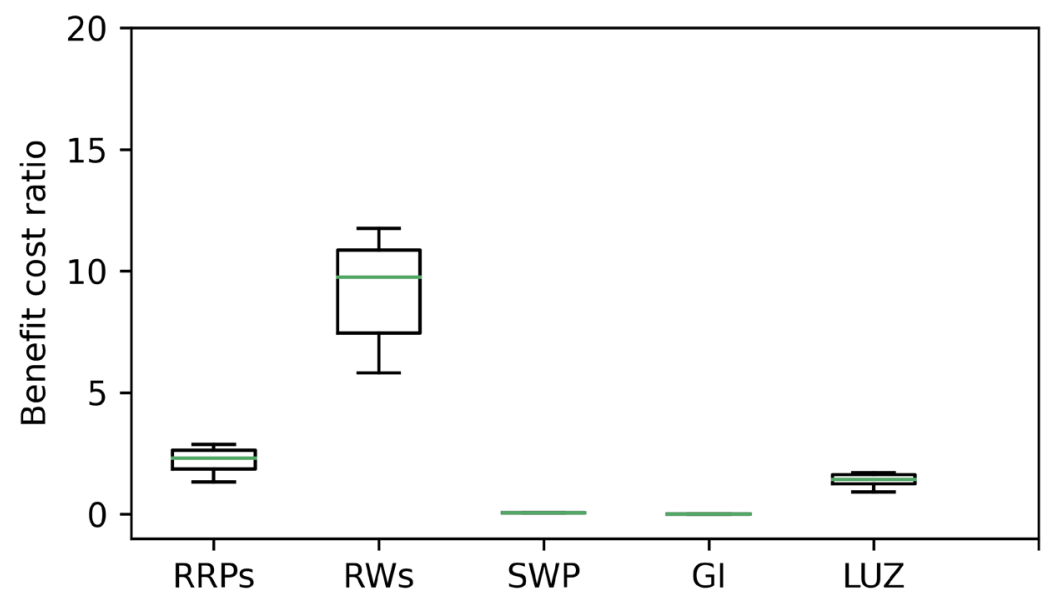

Figure 4. Boxplot for the benefit cost ratio of each adaptation measure for the near-future flood risk. 
results in reducing future flood risk. Most of them could alleviate not only the magnitude but also the uncertainty of future floods. However, two of them, namely, RWs and SWP, fail to reduce the uncertainty. Based on the results, RRPs could decrease flood magnitude and uncertainty for the near future by $33.2 \%$ and $36.4 \%$, respectively, which are higher than the values of the other structural adaptation measures. On the other hand, controlling land subsidence could avoid higher flood risks in the future. Faster resolution of the land subsidence problem could provide more benefits in future flood prevention. Applying flood structural adaptation measures that have the additional benefit of recharging groundwater could be one solution to prevent the land subsidence rate, namely, RRPs and RWs. Abidin et al. [13] found that groundwater extraction contributed to the land subsidence rate in Jakarta. Shi et al. [40] showed evidence that the artificial recharge of groundwater could increase the groundwater level. If flood adaptation measures are installed, they are expected to not only reduce flood risk but also prevent severe land subsidence.

Furthermore, as a megacity, Jakarta is also facing other environmental problems, such as air pollution. Resosudarmo and Napitupulu [41] predicted that the economic costs in Jakarta in 2015 due to air pollution would be 4384 billion IDR (approximately 451 million USD using the 2005 conversion rate). Even though the reduction in flood damage due to GI was smaller than that due to the other measures, it could reduce carbon emissions in the atmosphere. We can estimate the additional benefit of GI with regard to the reduction in carbon emissions by using the guidebook from the Center for Neighborhood Technology [42]. By assuming that the GI covers all of the urban areas and that the type of GI is a green roof, we can estimate an annual sequestered carbon amount of 242 thousand tonnes for the whole watershed based on the land use projected in 2050 (equivalent to a value of 15 million USD). These results indicate that the benefit of utilizing GI to reduce flood risks (which is valued at 48 million USD) is higher than that to reduce carbon emissions.

Some capital cities in Southeast Asia also face similar problems as those in Jakarta. Pillai et al. [43] reported that three megacities in Southeast Asia, namely, Bangkok, Ho Chi Minh City (HCMC) and Manila, could be facing worsening flood problems due to climate change and urbanization. They also reported proposed adaptation measures for each city. A combination of improved drainage pumping and coastal erosion protection was proposed to reduce the flood risk in Bangkok. These measures could reduce the inundation area for floods with a 30 -year return period by $51 \%$. In Manila, an investment to reduce floods with 30-year return periods in climate change scenarios could provide a net present value (NPV) of 9 billion PHP. However, an investment to reduce floods with a 5-year return period would provide a negative NPV of -0.5 billion PHP. HCMC has already proposed the construction of a system of flood measures that will significantly change the pattern of flooding and the hydrology of the city. The project would reduce damage costs by $35 \%$. For a comparison with the results of this study, the reductions in the damage costs due to the application of 
the adaptation measures in the study area vary from $2.1 \%$ to $33.8 \%$, and the recharge and infiltration ponds have higher potentials to reduce flood damage compared with that of the other structural adaptation measures. In addition, migrating vital assets to safer places could be an option to avoid higher damage due to future flooding. Currently, the Indonesian government plans to shift the capital cities to Kalimatan Island [44] at an estimated cost of approximately 33 billion USD. The capital shifting costs are much higher compared to those of the proposed adaptation measures in this paper, excluding GI and SWP. Although moving the capital city could avoid higher flood damage, the remaining asset, the old capital, should be protected from future floods.

Coombes [45] provided a perspective of stormwater management to face future floods. He suggested integrated stormwater management with continuous improvement could produce solutions that respond to multiple objectives, including economic, social, and environmental criteria. This study succeeds in evaluating several flood adaptation measures, either structural or nonstructural, to alleviate future floods in a megacity. Some of them also have an additional benefit to the environment (i.e., RRPs, RWs, and GI). These findings are expected to provide more insights to policymakers in managing the stormwater in a megacity.

\section{Conclusions}

This study evaluated the effectiveness of several adaptation measures in reducing the magnitude and uncertainty of flood risks under future scenarios. A flood inundation model and a flood damage costs model were employed to assess the effectiveness of those adaptation measures. The future scenarios consisted of land use changes, land subsidence, and climate change. Additionally, both structural and nonstructural adaptation measures were applied in the models. According to the results, RRPs have the potential to reduce the magnitude and uncertainty of flood risks by $33.2 \%$ and $36.4 \%$, respectively, which are higher than the potentials of the other structural adaptation measures. Among the nonstructural adaptation measures, managing land use zones could alleviate the magnitude of flood risks by $29.0 \%$, with an uncertainty reduction of $19.9 \%$.

Our findings demonstrate that the megacities of developing countries should take some initiatives to reduce flood risks due to environmental changes. They should consider applying multi-benefit adaptation measures that could not only reduce flood damage costs but also alleviate other problems such as land subsidence and air pollution. In addition, this study shows examples of multi-benefit adaptation measures that could be applied in other megacities.

\section{Acknowledgements}

This research was supported by the Environment Research and Technology Development Fund (S-14) of the Ministry of the Environment of the Government of Japan. 


\section{Conflicts of Interest}

The authors declare no conflicts of interest regarding the publication of this paper.

\section{References}

[1] Hirabayashi, Y., et al. (2013) Global Flood Risk under Climate Change. Nature Climate Change, 3, 816-821. https://doi.org/10.1038/nclimate1911

[2] Bradshaw, C.J.A., Sodhi, N.S., Peh, K.S.-H. and Brook, B.W. (2007) Global Evidence That Deforestation Amplifies Flood Risk and Severity in the Developing World. Global Change Biology, 13, 2379-2395. https://doi.org/10.1111/j.1365-2486.2007.01446.x

[3] Januriyadi, N.F., Kazama, S., Moe, I.R. and Kure, S. (2018) Evaluation of Future Flood Risk in Asian Megacities: A Case Study of Jakarta. Hydrological Research Letters, 12, 14-22. https://doi.org/10.3178/hrl.12.14

[4] Moe, I.R., Kure, S., Farid, M., Udo, K., Kazama, S. and Koshimura, S. (2015) Numerical Simulation of Flooding in Jakarta and Evaluation of a Counter Measure to Mitigate Flood Damage. Journal of Japan Society of Civil Engineers, Ser. G, 71, I_29-I_35. https://doi.org/10.2208/jscejer.71.I_29

[5] Radhakrishnan, M., et al. (2018) Coping Capacities for Improving Adaptation Pathways for Flood Protection in Can Tho, Vietnam. Climatic Change, 149, 29-41. https://doi.org/10.1007/s10584-017-1999-8

[6] Dyer, M. (2004) Performance of Flood Embankments in England and Wales. Proceedings of the Institution of Civil Engineers - Water Management, 157, 177-186.

[7] Van Wesenbeeck, B.K., de Boer, W., Narayan, S.W., van der Star, R.L. and de Vries, M.B. (2017) Coastal and Riverine Ecosystems as Adaptive Flood Defenses under a Changing Climate. Mitigation and Adaptation Strategies for Global Change, 22, 1087-1094. https://doi.org/10.1007/s11027-016-9714-Z

[8] Vuik, V., Jonkman, S.N., Borsje, B.W. and Suzuki, T. (2016) Nature-Based Flood Protection: The Efficiency of Vegetated Foreshores for Reducing Wave Loads on Coastal Dikes. Coastal Engineering, 116, 42-56. https://doi.org/10.1016/j.coastaleng.2016.06.001

[9] Stark, J., Plancke, Y., Ides, S., Meire, P. and Temmerman, S. (2016) Coastal Flood Protection by a Combined Nature-Based and Engineering Approach: Modeling the Effects of Marsh Geometry and Surrounding Dikes. Estuarine, Coastal and Shelf Science, 175, 34-45. https://doi.org/10.1016/j.ecss.2016.03.027

[10] Parker, D., Tunstall, S. and Wilson, T. (2005) Socio-Economic Benefits of Flood Forecasting and Warning. International Conference on Innovation Advances and Implementation of Flood Forecasting Technology, Tromsø, 17-19 October 2005, 11.

[11] Pilarczyk, K.W. and Nuoi, N.S. (2005) Experience and Practices on Flood Control in Vietnam. Water International, 30, 114-122. https://doi.org/10.1080/02508060508691843

[12] Farid, M., Mano, A. and Udo, K. (2011) Modeling Flood Runoff Response to Land Cover Change with Rainfall Spatial Distribution in Urbanized Catchment. Journal of JSCE, 67, I_19-I_24. https://doi.org/10.2208/jscejhe.67.I_19

[13] Abidin, H.Z., Andreas, H., Gumilar, I., Fukuda, Y., Pohan, Y.E. and Deguchi, T. (2011) Land Subsidence of Jakarta (Indonesia) and Its Relation with Urban Development. Natural Hazards, 59, 1753-1771. 
https://doi.org/10.1007/s11069-011-9866-9

[14] Moe, I.R., Kure, S., Farid, M., Udo, K., Kazama, S. and Koshimura, S. (2016) Evaluation of Flood Inundation in Jakarta Using Flood Inundation Model Calibrated by Radar Rainfall. Journal of JSCE, Ser. B1, 72, I_1243-I_1248.

https://doi.org/10.2208/jscejhe.72.I_1243

[15] The HadGEM2 Development Team: G. M. Martin, et al. (2011) The HadGEM2 Family of Met Office Unified Model Climate Configurations. Geoscientific Model Development, 4, 723-757.

[16] Jeffrey, S., et al. (2013) Australia's CMIP5 Submission Using the CSIRO-Mk3.6 Model. Australian Meteorological and Oceanographic Journal, 63, 1-14. https://doi.org/10.22499/2.6301.001

[17] Chylek, P., Li, J., Dubey, M.K., Wang, M. and Lesins, G. (2011) Observed and Model Simulated 20th Century Arctic Temperature Variability: Canadian Earth System Model CanESM2. Atmospheric Chemistry and Physics, Discussions, 11, 22893-22907. https://doi.org/10.5194/acpd-11-22893-2011

[18] Giorgetta, M.A., et al. (2013) Climate and Carbon Cycle Changes from 1850 to 2100 in MPI-ESM Simulations for the Coupled Model Intercomparison Project Phase 5: Climate Changes in MPI-ESM. Journal of Advances in Modeling Earth Systems, 5, 572-597. https://doi.org/10.1002/jame.20038

[19] Watanabe, S., et al. (2011) MIROC-ESM 2010: Model Description and Basic Results of CMIP5-20c3m Experiments. Geoscientific Model Development, 4, 845-872. https://doi.org/10.5194/gmd-4-845-2011

[20] Dunne, J.P., et al. (2012) GFDL's ESM2 Global Coupled Climate-Carbon Earth System Models. Part I: Physical Formulation and Baseline Simulation Characteristics. Journal of Climate, 25, 6646-6665. https://doi.org/10.1175/JCLI-D-11-00560.1

[21] Dufresne, J.-L., et al. (2013) Climate Change Projections Using the IPSL-CM5 Earth System Model: From CMIP3 to CMIP5. Climate Dynamics, 40, 2123-2165. https://doi.org/10.1007/s00382-012-1636-1

[22] Voldoire, A., et al. (2013) The CNRM-CM5.1 Global Climate Model: Description and Basic Evaluation. Climate Dynamics, 40, 2091-2121. https://doi.org/10.1007/s00382-011-1259-y

[23] MLIT (2005) The Flood Control Economy Investigation Manual (Proposed). Ministry of Land, Infrastructure, Transport and Tourism.

http://www.mlit.go.jp/river/basic_info/seisaku_hyouka/gaiyou/hyouka/h1704/chisu i.pdf

[24] Kazama, S., Sato, A. and Kawagoe, S. (2009) Evaluating the Cost of Flood Damage Based on Changes in Extreme Rainfall in Japan. Sustainability Science, 4, 61-69. https://doi.org/10.1007/s11625-008-0064-y

[25] Zhou, Q., Mikkelsen, P.S., Halsnæs, K. and Arnbjerg-Nielsen, K. (2012) Framework for Economic Pluvial Flood Risk Assessment Considering Climate Change Effects and Adaptation Benefits. Journal of Hydrology, 414-415, 539-549. https://doi.org/10.1016/j.jhydrol.2011.11.031

[26] Kreibich, H. and Dimitrova, B. (2010) Assessment of Damages Caused by Different Flood Types. FRIAR 2010, Milan, 3-11. https://doi.org/10.2495/FRIAR100011

[27] Honma, J. (1940) Discharge Coefficient for Trapezoidal Weir. Journal of Japan Society of Civil Engineers, 26, 635-645.

[28] Bouwer, H. (2002) Artificial Recharge of Groundwater: Hydrogeology and Engineering. Hydrogeology Journal, 10, 121-142. 
https://doi.org/10.1007/s10040-001-0182-4

[29] Januriyadi, N.F., Kazama, S., Moe, I.R. and Kure, S. (2017) Estimation of Spatial Flood Damage Costs in Jakarta, Indonesia. Proceedings of the 37 th IAHR World Congress, Kuala Lumpur, 2343-2349.

[30] Colven, E. (2017) Understanding the Allure of Big Infrastructure: Jakarta's Great Garuda Sea Wall Project. Water Alternatives, 10, 250-264.

[31] Connop, S., et al. (2016) Renaturing Cities Using a Regionally-Focused Biodiversity-Led Multifunctional Benefits Approach to Urban Green Infrastructure. Environmental Science \& Policy, 62, 99-111. https://doi.org/10.1016/j.envsci.2016.01.013

[32] Farrugia, S., Hudson, M.D. and McCulloch, L. (2013) An Evaluation of Flood Control and Urban Cooling Ecosystem Services Delivered by Urban Green Infrastructure. International Journal of Biodiversity Science, Ecosystem Services \& Management, 9, 136-145. https://doi.org/10.1080/21513732.2013.782342

[33] Idiata, D. (2016) Understanding the Role of Green Infrastructure (GI) in Tackling Climate Change in Today's World. International Journal of Environment and Sustainability, 5, 35-45. https://doi.org/10.24102/ijes.v5i1.661

[34] Moe, I.R., et al. (2017) Future Projection of Flood Inundation Considering Land-Use Changes and Land Subsidence in Jakarta, Indonesia. Hydrological Research Letters, 11, 99-105. https://doi.org/10.3178/hrl.11.99

[35] Pupera, D.C.K. (2015) Prosedur Operasional Baku (POB): Penyusunan Baseline Data 100-0-100 Program Peningkatan Kualitas Permukiman (P2KP). Kementerian Pekerjaan Umum dan Perumahan Rakyat Direktorat Jenderal Cipta Karya, Jakarta.

[36] Black, R., Bennett, S.R.G., Thomas, S.M. and Beddington, J.R. (2011) Migration as Adaptation. Nature, 478, 447-449. https://doi.org/10.1038/478477a

[37] Varquez, A.C.G., Darmanto, N., Kawano, N., Takakuwa, S., Kanda, M. and Xin, Z. (2017) Representative Urban Growing Scenarios for Future Climate Models. Journal of Japan Society of Civil Engineers, Ser. B1 (Hydraulic Engineering), 73, I_103-I_108. https://doi.org/10.2208/jscejhe.73.I_103

[38] JICA (2013) The Project for Capacity Development of Jakarta Comprehensive Flood Management in Indonesia Technical Cooperation Report Comprehensive Flood Management Plan. JICA, Jakarta.

[39] The Guardian (2016) \$40 Bn to Save Jakarta: The Story of the Great Garuda. Cities, the Guardian.

https://www.theguardian.com/cities/2016/nov/22/jakarta-great-garuda-seawall-sink ing

[40] Shi, X., Jiang, S., Xu, H., Jiang, F., He, Z. and Wu, J. (2016) The Effects of Artificial Recharge of Groundwater on Controlling Land Subsidence and Its Influence on Groundwater Quality and Aquifer Energy Storage in Shanghai, China. Environmental Earth Sciences, 75, 195. https://doi.org/10.1007/s12665-015-5019-x

[41] Resosudarmo, B.P. and Napitupulu, L. (2004) Health and Economic Impact of Air Pollution in Jakarta. Economic Record, 80, S65-S75. https://doi.org/10.1111/j.1475-4932.2004.00184.x

[42] CNT and American Rivers (2010) The Value of Green Infrastructure: A Guide to Recognizing Its Economic, Environmental and Social Benefits.

[43] Pillai, P., Philips, B.R., Shyamsundar, P., Ahmed, K. and Wang, L. (2010) Climate Risks and Adaptation in Asian Coastal Megacities: A Synthesis Report. The World Bank, Washington DC.

http://documents.worldbank.org/curated/en/866821468339644916/Climate-risks-an 
d-adaptation-in-Asian-coastal-megacities-a-synthesis-report

[44] The Jakarta Post (2019) Jokowi to Announce New Indonesia Capital to Replace Jakarta-Business-The Jakarta Post.

https://www.thejakartapost.com/news/2019/08/26/jokowi-to-announce-new-indone sia-capital-to-replace-jakarta.html

[45] Coombes, P.J. (2018) Status of Transforming Stormwater Drainage to a Systems Approach to Urban Water Cycle Management-Moving beyond Green Pilots. Australasian Journal of Water Resources, 22, 15-28.

https://doi.org/10.1080/13241583.2018.1465376 